\title{
Soft Skills and Positive Attitude : Science of Bridging Gap
}

\author{
Suman Gupta, Neetu Mishra Shukla, Indu Babra Kumar
}

\begin{abstract}
Soft skills are those essential traits and expertise that must be acquired by every person to be successful in life. These abilities, traits or skills are also most popularly called people's skills and in recent times, also known as twenty first century skills. It is proven that the hard skills or the academic or professional qualifications maybe an inevitable component of any kind of employment or job placement but the success of a person depends upon the soft skills he has. Research has shown that attitude of the pupils and development or enhancement of these skills is correlated. The attitude is different in each individual and therefore the real life application of these skills is also varied. The study undertaken endeavours to find out the correlation between the positive attitude and negative attitude of the students towards soft skills and the real life application of it.
\end{abstract}

Key words : Positive attitude, Negative attitude, Application, Soft Skills

\section{INTRODUCTION}

Those skills set that are necessary for any person to be well established in life are called Soft Skills These skills include the interpersonal skills, people's skills, negotiation skills, communication skills, personality or personality traits, professional attributes, social intelligence and emotional intelligence, enabling people to harness the best possible solution to any problem in life. It actually helps one collaborate well with others, perform satisfactorily, and in reality these skills promote the efficacy of hard skills. Achieving any set goal becomes easy with the use of soft skills. These skills also known as twenty first century skills include collaborative work, ethics, creativity, critical thinking, lifelong learning, leadership to name a few. The 4Cs namely communication, collaboration, critical thinking and creativity which come under the umbrella of soft skills are essential in any classroom teaching activity, in any work place and beyond.

Revised Manuscript Received on December 30, 2019.

* Correspondence Author

Suman Gupta*, Research Scholar, Amity Institute of Education, Amity University, Noida, (U.P) India. Email : sumandagur@ymail.com

Neetu Shukla Mishra, Asst. Professor III, Amity Institute of Education, Amity University, Noida, (U.P) India. Email : nmishra@amity.edu

Indu Babra Kumar, Professor, Head, Department of ICT \& Training Division, CIET, NCERT, New Delhi, India. Email: induk.babra@gmail.com

(C) The Authors. Published by Blue Eyes Intelligence Engineering and Sciences Publication (BEIESP). This is an open access article under the CC BY-NC-ND license (http://creativecommons.org/licenses/by-nc-nd/4.0/)

\section{NEED OF THE STUDY}

Marcel, M. R.(2012). 'Executive perceptions of the 10 main soft skills needed in today's workplace' (2012). In his work, he mentioned that there are 10 soft skills which are considered important in the world of employment by the business executives. Some of them are communication, responsibility, work ethic, positive attitude, professionalism, teamwork. He goes on to explain that in earlier times the hard skills, were the only requirement for professional employment; but today's situation has undergone a drastic change. The technical skills are not enough for employment as soft skills has gained prominence. This has also raised questions about the quality of the graduates' job market and the ability of graduates to meet the needs of employers. There definitely exists a gap between the employment sector or the job market and the education provided in the technical or professional institutes which needs to be bridged.

Sokklingam, S. (2014). 'Study on the employability skills of M.B.A. Students in Engineering Colleges' examined the students' perception regarding employability skills. The findings revealed that significant mean differences exist between the students' personal variables on the Employability Skills factors. The review of the literature on the soft skills points out that hard skills leads to only $15 \%$ of a person's success, on the other hand, the remaining $85 \%$ is contributed by the soft skills. If we look at the employers' perspective, they look for people who have good communication skills, negotiation abilities, positive attitude, zeal for team work or collaboration and a knack for problem solving or trouble shooting. Unfortunately, these skills are not specifically taught in most of the professional colleges from where these employers hire the human resource. Hence, they end up selecting a few who are not just professionally qualified but are adept at these soft skills. The economic liberalization, and globalization of the Indian market, puts more pressure on these institutes for inculcating people's skills in young generation enabling them to harness and exhibit their true potential at the domestic and international levels. Understanding the importance of this important aspect recently raised, most educational institutions in India have initiated and incorporated programs, projects or activities to develop social skills in their students. Most people recognize that the acquisition and development of social skills are important to progress in life and work. The Draft, national Education Policy (2019), talks about holistic development of learners as it clearly states that 'the goal will be to create holistic and complete individuals equipped with key $21^{\text {st }}$ century skills'.

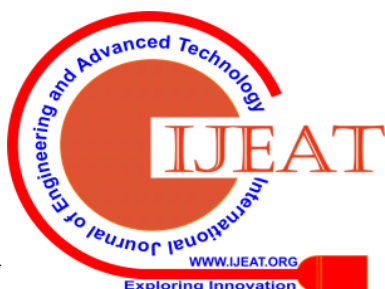


While recommending changes in the present scenario it emphatically mentions that the curriculum of the schools will be reoriented and the aim will be to develop holistic learners. Higher order skills such as critical thinking, reasoning, creativity, logical deduction, collaboration/team work, social responsibility must be developed among the learners.

Since, there is an understanding of the need to inculcate and enhance these soft skills in all learners, it becomes imperative to analyse what factors would be essential to promote the growth of these skills in young learners. The positive attitude or the negative attitude of the learners certainly impacts the development of soft skills. This means that positive attitude of a person influences the real life application of these skills set.

\section{STATEMENT OF THE PROBLEM}

A Study Of Attitude Of Senior Secondary School Students Towards Soft Skills And Its Real Life Application

\section{OBJECTIVE OF THE STUDY}

1. To find out the relationship based on two dimensions of attitude: positive attitude and negative attitude, towards soft skills and its real life application

HYPOTHESIS There is no significant relationship based on two dimensions of attitude: positive attitude and negative attitude towards soft skills and its real life application

\section{RESEARCH DESIGN}

The list of soft skills as defined by various researchers and experts is very exhaustive. Most importantly only a few skills are developed and enhanced in the learners of any school. Only three soft skills were chosen for the current study, i.e. critical thinking, problem solving and communication skills. Self-developed tools were standardised and thereafter used for data collection. The tools used to collect data were:

Attitude Scale for Assessment of Soft Skills in School Students (ASASS) - A five point likert scale was developed and divided into three segments, to assess the attitude of the senior secondary school students towards soft skills. There were 30 items on the attitude scale which were ascertained to test the positive attitude or the negative attitude of the students. 15 statements reflected negative and 15 reflected positive attitude of the students while all were in a mixed bag. The tool was found to be reliable as cronbach alpha coefficient calculated determined so.

Soft Skills Proficiency Test for Students (SSPT)- The proficiency test developed by the researcher was used as the second tool, to assess the real life application of soft skills. This was a 27 item, three segment test developed in which real life situation statements were also incorporated. The content validity was checked and the test-retest method was used to check the reliability of the Proficiency test.

\section{Population and Sample}

The population considered for the study was the senior secondary school students of all the government and private schools of New Delhi. In order to select the sample, Purposive sampling method was used and the South west B zone of Delhi became the sample. Finally, 150 students from the 3 private senior secondary schools and 150 students from the 3 government senior secondary schools of South West B Zone of New Delhi, were selected to collect the data which contributed to the sample.

\section{FINDINGS AND DISCUSSIONS}

After the employing ASASS, data was collected to find out the positive attitude or the negative attitude of the senior secondary school students using ASASS. Further, the real life applicability of the soft skills was found through SSPT. The data collected was thereafter subjected to analysis.

Analysis of Table 1:

- the analysis indicated that for Positive attitude, Pearson coefficient Correlation (r-value) is 0.80

- the analysis indicated that for Negative attitude, Pearson coefficient Correlation (r-value) is 0.77 .

- it was found that the positive attitude is higher so the applicability is higher.

- it was found that the $\mathrm{p}$-value is $<.00001$ for positive attitude. Hence, the result is significant at $\mathrm{p}<.05$ for positive attitude. - it was found that the $\mathrm{p}$-value is $<.00001$ for negative attitude. Hence, the result is significant at $\mathrm{p}<.05$ for negative attitude. - it was found that the positive attitude mean 41.56 is higher than the negative attitude mean 38.58

Thus, it can be stated that there is a significant relationship based on two dimensions of attitude: positive attitude and negative attitude towards soft skills and its real life application. The hypothesis stands rejected at .05 level of significance.

BAR DIAGRAM 1, showing MEAN difference showing significant relationship based on two dimensions of attitude: positive attitude and negative attitude towards soft skills and its real life application

\section{MEAN difference}

42

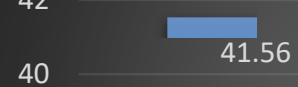

40

38 38.58

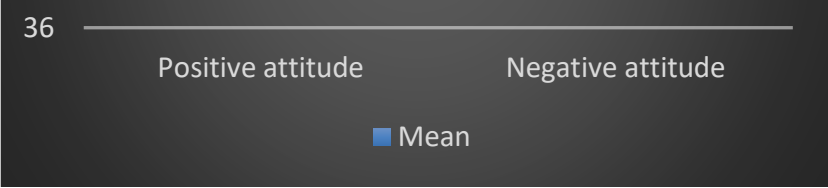

The mean of positive attitude is 41.56 and the mean of negative attitude is 38.58 . The mean of positive attitude is higher than the negative attitude mean. This shows that the students have the positive attitude towards soft skills. Since the positive attitude is higher it is obvious that the positive applicability towards soft skill is higher in real life among senior secondary students.

The entire attitude Mean, be it positive or negative is 80.21 and the applicability is only 10.70 . This shows that the attitude towards the soft skill is high among the senior secondary students but their applicability is poor in real life. This may be because the positive attitude mean is 41.56 but the negative attitude mean is 38.58 .

Table 1 


\begin{tabular}{|c|c|c|c|c|c|}
\hline $\begin{array}{l}\text { ASASS } \\
\text { ITEM No.s }\end{array}$ & $\begin{array}{l}\text { SSPT } \\
\text { ITEM } \\
\text { No.s }\end{array}$ & $\begin{array}{l}\text { DIMENSIONS } \\
\text { ATTITUDE }\end{array}$ & $\begin{array}{l}\text { VARIABLE-1 } \\
\text { Attitude } \\
\text { MEAN } \\
\text { Sample=300 }\end{array}$ & $\begin{array}{l}\text { VARIABLE-2 } \\
\text { Applicability } \\
\text { MEAN } \\
\text { Sample=300 }\end{array}$ & r-value \\
\hline $\begin{array}{l}\text { 1.1, 1.3, 1.4, 1.9, 1.10, 2.1, 2.3, } \\
2.5,2.6,2.9,3.1,3.4,3.5,3.6 \\
3.10\end{array}$ & $1.1-3.8$ & Positive attitude & 41.56 & 10.70 & 0.80 \\
\hline $\begin{array}{l}1.2,1.5,1.6,1.7,1.8,2.2,2.4 \\
2.7,2.8,2.10,3.2,3.3,3.7,3.8 \\
3.9\end{array}$ & & Negative attitude & 38.58 & & 0.77 \\
\hline
\end{tabular}

*significant at.05 level

FIG.1. SCATTER DIAGRAM showing significant relationship based on two dimensions of attitude: positive attitude and negative attitude towards soft skills and its real application of soft skills.

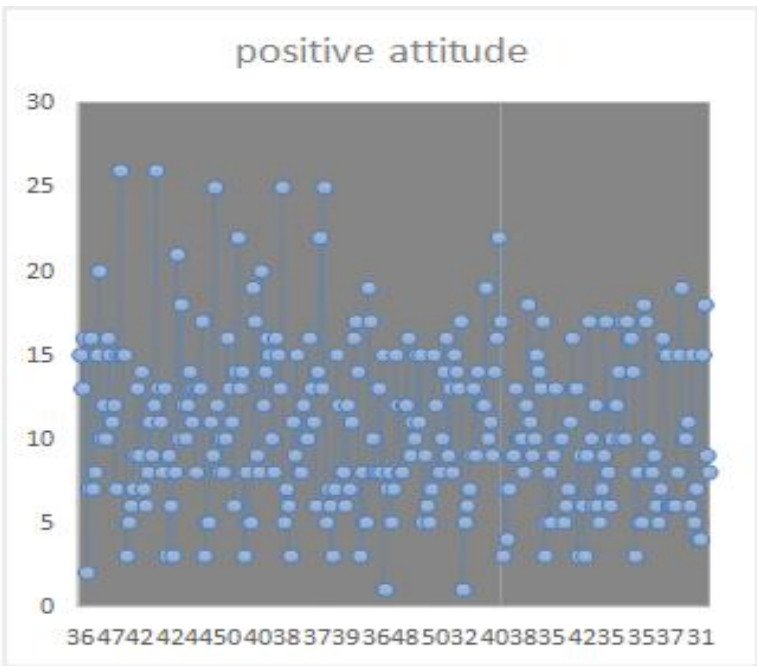

FIG.2: BAR DIAGRAM showing MEAN difference showing significant relationship based on two dimensions of attitude: positive attitude and negative attitude towards soft skills and its real life application

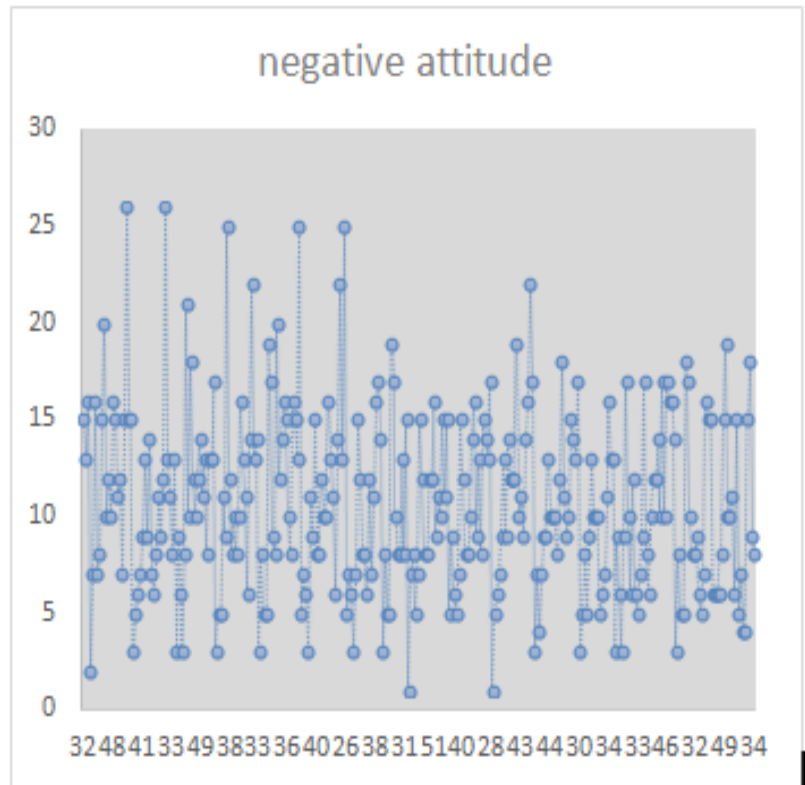

All the findings and analysis show that the attitude of the learners must be shifted to positive attitude so that the skill acquisition becomes smooth and real life application becomes better.

It is the responsibility of all the stakeholders who profess to build and shape the future of the country with education as one of the most important tools, curricular changes are made to incorporate soft skills learning at school. The responsibility rests not just with the policy makers, parents, teachers and heads of the institutions imparting education at all levels equally share this responsibility.

\section{CONCLUSION}

The findings of the study prove that the inculcation and development of soft skills and real life application of these skills depends upon the positive attitude or the negative attitude of the students towards these skills. The need for inculcating soft skills in young learners is felt not only by the employers but also by the policy makers who are instrumental in shaping the future of young achievers through curricular changes. It is important now for those imparting education to intertwine the assimilation and development of soft skills in the regular classroom teaching practice and also develop a positive attitude in the learners towards the acquisition of these skills. Equipped with these set of skills, the young generation will stand a better chance of progress and success.

\section{REFERENCES}

2. Gupta S (2019). Harness Soft Skills to Everyday Life : A Scientific Technique to Gain Success. International Journal of Innovative Technology and Exploring Engineering (IJITEE) ISSN: 2278-3075, Volume-8 Issue-12, October 2019

3. Sokkalingam SRM (2014). Study on the Employability Skills of MBA Students in Engineering Colleges. (Doctoral Dissertation). Available from Shodhganga@INFLIBNET (URI: http//hdl.handle.net/10603/56349)

4. Robles, M. Marcel (2012). Executive Perceptions of the Top 10 Soft Skills Needed in Today's Workplace. Business Communication Quarterly, 75(4), 453-465. DOI : 10.1177/1080569912460400

5. National Curriculum Framework (2005). NCERT : New Delhi. Position Paper on Teaching of English, Health and Physical Education, Education for Peace

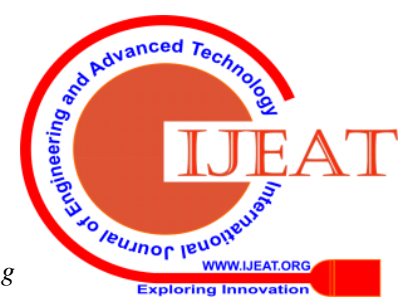


Soft Skills and Positive Attitude : Science of Bridging Gap

\section{WEBLIOGRAPHY}

https://www.ijitee.org/wp-content/uploads/papers/v8i12/L29 311081219.pdf

https://innovate.mygov.in/wp-content/uploads/2019/06/myg ov15596510111.pdf

\section{AUTHORS PROFILE}

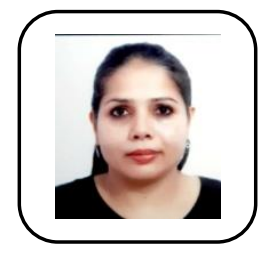

Suman Gupta, MA English form Delhi University and M.Ed from Jammu University, is presently enrolled as a Research Scholar at Amity University Noida and is pursuing her research work in the area of Soft Skills. She is also working as an English Language teacher in a reputed Public school of Delhi and teaches the students of Senior Secondary level. She has taken a lot of workshops with the teachers of English language, has worked with NCERT contributing to the development of teachers handbook for class VII and VIII, and has published a few papers on Soft Skills.

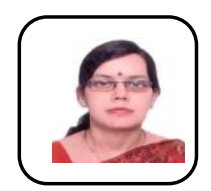

Dr. Neetu Mishra Shukla is a PostGraduate in English and has also done her M.ED. and has a doctorate in Education. She has a 12 yrs. teaching experience at Amity University, Noida UP. She has many publications to her credit and has worked in a variety of areas such as Gender, Communication, Peace Education, Curriculum and Teaching Strategies for children to name a few.

Dr. Indu Kumar is heading Department of ICT and Training Division at Central Institute of Educational Technology, NCERT. She is leading in a number of ICT in Education Initiatives. Some of the prominent ones include development of ICT in Education Curriculum for Teachers and Students, National Repository of Open Educational Resources (a storehouse of 13663 digital Resources), Development and dissemination of Massive Open Online Courses, development and maintenance of e pathshala mobile app and portal, digital content development, development of mobile apps for various educational purposes. The Multi Media Interactive Contents developed by her and two animations conceptualized, produced and directed by her won National Award in "All India Children's Educational Audio Video Festival. She has also received Digital India Award for ePathshala as the best mobile app. She has made considerable contributions in educational Innovations and Design of Training Courses and Course Curricula 